\title{
Eating disorders and obesity: two sides of the same coin?
}

\author{
JEMMA DAY, ANDREW TERNOUTH, DAVID A. COLLIER
}

\begin{abstract}
The eating disorders anorexia and bulimia nervosa have traditionally been regarded as entirely separate from obesity. Eating disorders have been regarded as Western culture-bound syndromes, arising in societies with excessive emphasis on weight, shape and appearance, and best treated by psychological therapies, in particular cognitive behavioural therapy or familybased interventions. In contrast, obesity has been considered a medical illness with metabolic and genetic origins, and thought to be best treated by mainstream medicine, involving dietary, drug or surgical treatment. We believe that this polarisation is fundamentally flawed, and research and treatment of both types of disorder would be better served by greater appreciation of the psychosocial components of obesity and the biological and genetic components of eating disorders. There are similarities in phenotype (such as excessive attempts at weight control, binge eating behaviours) and in risk factors (such as low self-esteem, external locus of control, childhood abuse and neglect, dieting, media exposure, body image dissatisfaction, weight-related teasing and shared susceptibility genes). One example of shared genetic risk is the brain-derived neurotrophic factor (BNDF) gene, in which the valine allele of the Val66Met amino acid polymorphism predisposes to obesity, whereas the methionine allele predisposes to eating disorders. Thus the evidence suggests that these disorders will have both shared and distinct susceptibility factors; some will predispose to both types of disorder, some will push in opposite directions, and some will separate them.
\end{abstract}

Declaration of Interest: None.

Over the last 20 years obesity prevalence has reached epidemic proportions in many countries of the developed world (World Health Organization, 2000). Less frequently reported but also worrying has been the parallel rise in incidence at least of eating disorders such an Anorexia Nervosa (AN), Bulimia Nervosa $(\mathrm{BN})$ and Binge Eating Disorder (BED). Eating disorders have a much lower prevalence than obesity - the National Comorbidity Survey replication data (Hudson et al., 2007) found lifetime prevalence of $\mathrm{AN}, \mathrm{BN}$ and $\mathrm{BED}$ to be $0.9 \%, 1.5 \%$ and $3.5 \%$ respectively in females and $0.3 \%, 0.5 \%$ and $2 \%$ in males - but a recent study suggests the prevalence of eating disorders has increased over the past decade (Hay et al., 2008). Thus it seems that the same sociocultural changes in society may be increasing the incidence of both eating disorders and obesity.

However, sociocultural factors are only part of the risk for these disorders; both obesity and eating disorders are

Address for correspondence: Professor David A. Collier, Social Genetic and Developmental Psychiatry Centre, Institute of Psychiatry (King's College London), De Crespigny Park, Denmark Hill, London SE5 8AF (United Kingdom).

Fax: +44-20-7848.0802

E-mail: David.Collier@iop.kcl.ac.uk significantly and similarly heritable. Twins studies have shown that obesity, either defined by body mass index or adiposity is around 60-70\% genetic in origin (Stunkard et al., 1986). AN and $\mathrm{BN}$ have also been shown to be heritable, with twin studies also attributing around $60 \%$ of the variance to genetic factors (Bulik et al., 2000). History of parental obesity and also childhood obesity may differentiate $\mathrm{AN}$ from $\mathrm{BN}$ as both are risk factors for $\mathrm{BN}$ (Fairburn et al., 1999; Jacobi et al., 2004); this is consistent with the notion of partially shared genetic overlap between the two disorders. It is quite possible that a propensity to obesity interacts with dieting behaviour, given that obesity and $\mathrm{BN}$ are associated with dissatisfaction with weight, a desire to become slimmer (Shin et al., 2008), psychological distress (Gibson et al., 2008) and indeed, dieting itself (Terres et al., 2006).

Binge eating may represent the link between these disorders; $20-50 \%$ of people with obesity meet the criteria for binge eating disorder, whereas it is one of the diagnostic criteria for $\mathrm{BN}$; most women with $\mathrm{AN}$ also engage in binge-eating behaviour. Binge eating is a controversial measure as the diagnostic criteria may not be ideal (Bulik et al., 2008); also there is no simple definition, as it can involve either an objective or subjective loss of control over food consumption. However, it is heritable (Bulik et al., 1998) and thus very likely to represent shared genetic risk between these disorders. 
Despite reasonable efforts to identify genes involved in the aetiology of these disorders, there are a limited number of robust findings, especially for eating disorders, where molecular genetic research is a more recent activity. For obesity, the FTO gene has been identified as a genetic risk factor (Frayling et al., 2007), with the $16 \%$ of adults who are homozygous for the risk allele weighing about 3 kilograms more and having a 1.67-fold increased risk of obesity when compared with those not inheriting a risk allele. More recent studies have uncovered a further series of obesity genes, including MC4R, TMEM18, KCTD15, GNPDA2, SH2B1, MTCH2, NEGR1, BDNF and ETV5 (Loos et al., 2008; Willer et al., 2009; Thorleifsson et al., 2009).

Thus, one could argue that people homozygous for the obesity protective allele, who have less fat mass than the population on average, might be at increased risk of AN. On the other hand, since binge eating and family history of obesity are features of $\mathrm{BN}$, one could also argue that obesity genes will be shared with this diagnosis. Certainly for neuropsychiatric disorders such as bipolar disorder, schizophrenia, epilepsy and intellectual impairment, genetics has tended to clump disorders together rather than separate them (St Clair, 2009). However there are no large, well powered genetic studies of eating disorder which have addressed this issue, and the extent and nature of any shared risk genes genetic factors is largely unknown. However one intriguing finding is the association of Brain Derived Neurotrophic Factor (BDNF) with both obesity (Gunstad et al., 2006a; Thorleifsson et al., 2009) and eating disorders (Ribases et al., 2004), in consistent directions, i.e. the met66 allele of the valine66methionine polymorphism is associated with eating disorders and lower BMI and the val66 allele with higher BMI.

Socioeconomic status (SES) is one environmental factor which might differentiate between eating disorders and obesity (Taylor et al., 2005). SES shows a linear relationship with BMI, with higher rates of obesity in low SES groups and higher rates of eating disorders in high SES groups (O'Dea et al., 2008; Power et al., 2003; Nevonen et al., 2004). The higher rates of obesity in low SES groups can be attributed to the relatively low cost of high fat energy dense foods and lack of access or motivation to physical activity. Conversely, amongst high SES groups there will be an expanded range of diet choice, including more expensive foods such as food and vegetables, and propensity to exercise, greater pressure on weight and shape and higher parental expectations to succeed and conform.

Gender is also a factor. Women are disproportionately over-represented in both eating disorder and obesity (Hoek et al., 2003). The role of sex in modulating to weight and body fat distribution is undoubtedly metabolic but may also be due to differential sociocultural pressures on body shape, especially in relation to body dissatisfaction in women. Thus there is good evidence for shared risk factors between eating disorders and obesity involving dieting, media exposure, body image dissatisfaction and weight-related teasing (Haines \& NeumarkSztainer, 2006). Body dissatisfaction is found in obesity and across the eating disorder diagnoses (Troisi et al., 2006) and even part of the diagnostic criteria for AN, BN and BED (American Psychiatric Association, 1994). Likewise dieting is often a prominent risk factor in eating disorders, except for restricting anorexia, which has a constant low intake. Dieting with binging can also occur in weight gain and obesity (Roehrig et al., 2009), and is frequently found in obese individuals and those with eating disorders (Jacobi et al., 2004), particularly BN and BED.

Adolescence is the typical period of onset for EDs, The age of menarche has a common relationship with weight status being earlier in obese children and later in those who are underweight (Bau et al., 2009). Early menarche, controlled by hormone levels and affected by body fat content, is associated with obesity and early menarche and physical maturation and have been identified as risk factors for BN (Mangweth-Matzek et al., 2007).

Another risk factor which contributes towards both eating disorders and obesity is sexual abuse during childhood and adolescence (Rohede et al., 2008; PinhasHamiel et al., 2009). Sexual abuse has been shown to be a significant and even specific risk factor for eating disorders, again particularly those involving binge eating (Preti et al., 2006; Pawlowska et al., 2007). Sexual abuse is a commonly reported antecedent event in those affected by eating disorders, particularly BN (Sanci et al., 2008). A longitudinal study found those who were sexually abused as a child were at elevated risk for subsequent eating pathology in early adulthood (Johnson et al., 2002). Characteristically however, sexual and physical abuse are acknowledged as non-specific risk factors for BN, associated with general development of psychiatric illness, rather than representing risk factors specific only to the development of eating disorders (Jacobi et al., 2004). Although there is a paucity of research in the area, there is evidence that abuse and neglect are also substantial risk factors for the development of obesity (Gilbert et al., 2009; Gunstad et al., 2006b; Lissau \& Sørensen, 1994).

Stress and other psychological risk factors or trait disorders are seen in both eating disorders and obesity. Low self-esteem is common amongst sufferers of eating disorders (Brytek, 2006) which typically manifests as negative moods and depression; body dissatisfaction; social and

Epidemiologia e Psichiatria Sociale, 18, 2, 2009 
general anxiety and other internalising disorders. Likewise anxiety and depressive disorders are common comorbid diagnoses in individuals with eating disorders (Jordan et al., 2008) as is alcohol/drug abuse in those with eating disorders involving bingeing behaviours but not restrictive AN. This might suggest that traits commonly found in those with BN, BED, binge-purging AN and those reporting substance abuse, (namely impulsivity, high novelty-seeking, risk taking and reward response) mediate the link.

Whilst eating disorders are typically seen as based in psychological malfunction, psychological disorders are commonly thought of as stemming from obesity rather than being causative of obesity development. However there is some evidence that psychological ill health precedes obesity development (Pine et al., 2001; Hallstrom \& Noppa, 1981). Certainly obesity and overweight and eating disorders show common co-morbidities with poor psychological health. Obesity is associated with depression, anxiety (at least in women) low self-esteem, an external locus of control, behavioural problems, and even parental depression (Davis et al., 2008). Whilst some of these associations are no doubt a result of obesity, it is likely that the direction of causality runs both ways. Psychological ill health itself can cause disordered eating which in turn leads to obesity (Lee, 2007). A more external locus of control has also been linked with BN (Shisslak et al., 1990; Grace et al.,1985), AN (Harding \& Lachenmeyer, 1986), as well as disordered eating behaviours (Fouts et al., 2002) such as binge eating (Moyer et al., 1997). Some dimension of impulsivity is involved in obesity development (Goudie et al., 2008; Nederkoorn et al., 2006); for example disinhibited eating as measured by the Three factor eating questionnaire is associated with obesity (Yeomans et al., 2008). Impulsivity is considered a common trait in those with eating disorders and even considered a risk factor for the development of BN (Wonderlich et al., 2004; Fernandez-Aranda et al., 2008).

In summary, it is clear that disorder eating, which manifests itself as eating disorders with low or normal weight (e.g. AN and $\mathrm{BN}$ ) and obesity, have both commonalities and differences in aetiology. This aetiology is highly complex, consisting of many genetic and environmental risk factors which have a small effect and interact with each other. There will be risk factors which are distinct between eating disorders and obesity, individual shared risk factors such as the BDNF gene Vall66Met polymorphism which separate the phenotype by driving body fat composition in opposite directions, and fully shared risk factors such as childhood abuse and neglect.

\section{REFERENCES}

American Psychiatric Association (1994). Diagnostic and Statistical Manual of Mental Disorders, 4th ed. APA: Washington.

Bau A.M., Ernert A., Schenk L., Wiegand S., Martus P., Gruters A. \& Krude H. (2009). Is there a further acceleration in the age at onset of menarche? A cross-sectional study in 1840 school children focusing on age and bodyweight at the onset of menarche. European Journal of Endocrinology 160, 107-113.

Brytek A. (2006). Coping strategies, self-esteem and anger in French patients with anorexia nervosa. Psychology \& Health 21, 25-25.

Bulik C.M., Sullivan P.F. \& Kendler K.S. (1998). Heritability of binge-eating and broadly defined bulimia nervosa. Biological Psychiatry 44, 1210-1218.

Bulik C.M., Sullivan P.F., Wade T.D. \& Kendler K.S. (2000). Twin studies of eating disorders: a review. International Journal of Eating Disorders 27, 1-20.

Davis M., Young L., Davis S.P. \& Moll G. (2008). Parental depression, family functioning and obesity among African American children. Journal of Cultural Diversity 15, 61-65.

Fairburn C.G., Cooper Z., Doll H.A. \& Welch S.L. (1999). Risk factors for anorexia nervosa: three integrated case-control comparisons. Archives of General Psychiatry 56, 468-476.

Fernandez-Aranda F., Pinheiro A.P., Thornton L.M., Berrettini W.H., Crow S., Fichter M.M., Halmi K.A., Kaplan A.S., Keel P., Mitchell J., Rotondo A., Strober M., Woodside D.B., Kaye W.H. \& Bulik C.M. (2008). Impulse control disorders in women with eating disorders. Psychiatry Research 157, 147-157.

Fouts G. \& Vaughan K. (2002). Locus of control, television viewing, and eating disorder symptomatology in young females. Journal of Adolescence 25, 307-311.

Frayling T.M., Timpson N.J., Weedon M.N., Zeggini E., Freathy R.M., Lindgren C.M., Perry J.R., Elliott K.S., Lango H., Rayner N.W., Shields B., Harries L.W., Barrett J.C., Ellard S., Groves C.J., Knight B., Patch A.M., Ness A.R., Ebrahim S., Lawlor D.A., Ring S.M., BenShlomo Y., Jarvelin M.R., Sovio U., Bennett A.J., Melzer D., Ferrucci L., Loos R.J., Barroso I., Wareham N.J., Karpe F., Owen K.R., Cardon L.R., Walker M., Hitman G.A., Palmer C.N., Doney A.S., Morris A.D., Smith G.D., Hattersley A.T. \& McCarthy M.I. (2007). A common variant in the FTO gene is associated with body mass index and predisposes to childhood and adult obesity. Science 316(5826), 889-894.

Gibson L.Y., Byrne S.M., Blair E., Davis E.A., Jacoby P. \& Zubrick S.R. (2008). Clustering of psychosocial symptoms in overweight children. Australian and New Zealand Journal of Psychiatry $42,118-125$.

Gilbert R., Widom C.S., Browne K., Fergusson D., Webb E. \& Janson S. (2009. Burden and consequences of child maltreatment in high-income countries. Lancet 373(9657), 68-81.

Goudie A.J., Cole J.C., Sumnall H. \& Field M. (2008). Impulsivity related to "obesity" and alcohol use in young women. Appetite 51, 761761.

Grace P.S., Jacobson R.S. \& Fullager C.J. (1985). A pilot comparison of purging and non-purging bulimics. Journal of Clinical Psychology 41, 173-180.

Gunstad J., Schofield P., Paul R.H., Spitznagel M.B., Cohen R.A., Williams L.M., Kohn M. \& Gordon E. (2006a). BDNF Val66Met polymorphism is associated with body mass index in healthy adults. Neuropsychobiology 53, 153-156.

Gunstad J., Paul R.H., Spitznagel M.B., Cohen R.A., Williams L.M., Kohn M. \& Gordon E. (2006b). Exposure to early life trauma is associated with adult obesity. Psychiatry Research 30, 142, 31-37.

Haines J. \& Neumark-Sztainer D. (2006). Prevention of obesity and eating disorders: a consideration of shared risk factors. Health Education Research, 21, 770-82.

Hallstrom T. \& Noppa H. (1981). Obesity in women in relation to mental illness, social factors and personality traits. Journal of Psychosomatic Research 25, 75-82. 
Harding T.P. \& Lachenmeyer J.R. (1986). Family interaction patterns and locus of control as predictors of the presence and severity of anorexia nervosa. Journal of Clinical Psychology 42, 440-448.

Hay P.J., Mond J., Buttner P. \& Darby A. (2008). Eating disorder behaviors are increasing: findings from two sequential community surveys in South Australia. Plos One 3, e1541.

Hoek H.W., van Hoeken D: Review of the prevalence and incidence of eating disorders. International Journal of Eating Disorders 34, 383-396.

Hudson J.I., Hiripi E., Pope H.G. \& Kessler R.C. (2007: The prevalence and correlates of eating disorders in the national comorbidity survey replication. Biological Psychiatry 61, 348-358.

Jacobi C., Hayward C., de Zwaan M., Kraemer H.C. \& Agras W.S. (2004). Coming to terms with risk factors for eating disorders: Application of risk terminology and suggestions for a general taxonomy. Psychological Bulletin 130, 19-65.

Johnson J.G., Cohen P., Kasen S. \& Brook J.S. (2002). Childhood adversities associated with risk for eating disorders or weight problems during adolescence or early adulthood. American Journal of Psychiatry $159,394-400$

Jordan J., Joyce P.R., Carter F.A., Horn J., McIntosh V.V.W., Luty S.E., McKenzie J.M., Frampton C.M.A., Mulder R.T. \& Bulik C.M. (2008). Specific and nonspecific Comorbidity in anorexia nervosa. International Journal of Eating Disorders 41, 47-56.

Lee W.W. (2007). An overview of pediatric obesity. Pediatric Diabetes 8, Suppl 9, 76-87.

Lissau I. \& Sørensen T.I. (1994). Parental neglect during childhood and increased risk of obesity in young adulthood. Lancet 343(8893), 324-327.

Loos R.J., Lindgren C.M., Li S., Wheeler E., Zhao J.H., Prokopenko I., Inouye M., Freathy R.M., Attwood A.P., Beckmann J.S., Berndt S.I., Prostate, Lung, Colorectal, and Ovarian (PLCO) Cancer Screening Trial, Jacobs K.B., Chanock S.J., Hayes R.B., Bergmann S., Bennett A.J., Bingham S.A., Bochud M., Brown M., Cauchi S., Connell J.M., Cooper C., Smith G.D., Day I., Dina C., De S., Dermitzakis E.T., Doney A.S., Elliott K.S., Elliott P., Evans D.M., Sadaf Farooqi I., Froguel P., Ghori J., Groves C.J., Gwilliam R., Hadley D., Hall A.S., Hattersley A.T., Hebebrand J., Heid I.M.; KORA, Lamina C., Gieger C., Illig T., Meitinger T., Wichmann H.E., Herrera B., Hinney A., Hunt S.E., Jarvelin M.R., Johnson T., Jolley J.D., Karpe F., Keniry A., Khaw K.T., Luben R.N., Mangino M., Marchini J., McArdle W.L., McGinnis R., Meyre D., Munroe P.B., Morris A.D., Ness A.R., Neville M.J., Nica A.C., Ong K.K., O'Rahilly S., Owen K.R., Palmer C.N., Papadakis K., Potter S., Pouta A., Qi L., Nurses' Health Study, Randall J.C., Rayner N.W., Ring S.M., Sandhu M.S., Scherag A., Sims M.A., Song K., Soranzo N., Speliotes E.K., Diabetes Genetics Initiative, Syddall H.E., Teichmann S.A., Timpson N.J., Tobias J.H., Uda M., SardiNIA Study, Vogel C.I., Wallace C., Waterworth D.M., Weedon M.N., Wellcome Trust Case Control Consortium, Willer C.J., FUSION, Wraight, Yuan X., Zeggini E., Hirschhorn J.N., Strachan D.P., Ouwehand W.H., Caulfield M.J., Samani N.J., Frayling T.M., Vollenweider P., Waeber G., Mooser V., Deloukas P., McCarthy M.I., Wareham N.J., Barroso I., Jacobs K.B., Chanock S.J., Hayes R.B., Lamina C., Gieger C., Illig T., Meitinger T., Wichmann H.E., Kraft P., Hankinson S.E., Hunter D.J., Hu F.B., Lyon H.N., Voight B.F., Ridderstrale M., Groop L., Scheet P., Sanna S., Abecasis G.R., Albai G., Nagaraja R., Schlessinger D., Jackson A.U., Tuomilehto J., Collins F.S., Boehnke M. \& Mohlke K.L.(2008). Common variants near MC4R are associated with fat mass, weight and risk of obesity. Nature Genetics 40, 768-775.

Mangweth-Matzek B., Rupp C.I., Hausmann A., Kemmler G. \& Biebl W. (2007). Menarche, puberty, and first sexual activities in eating-disordered patients as compared with a psychiatric and a nonpsychiatric control group. International Journal of Eating Disorders 40, 705-710.

Moyer D.M., Di Pietro L., Berkowitz R.I. \& Stunkard A.J. (1997). Childhood sexual abuse and precursors of binge eating in an adolescent female population. International Journal of Eating Disorders 21, 23-30.
Nederkoorn C., Smulders F.T.Y., Havermans R.C., Roefs A. \& Jansen A. (2006). Impulsivity in obese women. Appetite 47, 253-256.

Nevonen L. \& Norring C. (2004). Socio-economic variables and eating disorders: a comparison between patients and normal controls. Eating and Weight Disorders 9, 279-284.

O'Dea J.A. (2008). Gender, ethnicity, culture and social class influences on childhood obesity among Australian schoolchildren: implications for treatment, prevention and community education. Health and Social Care in the Community 16, 282-290.

Pawlowska B. \& Masiak M. (2007). Comparison of socio-demographic data of female patients with purging and restricting types of anorexia nervosa hospitalised at the Psychiatry Department of the Medical University of Lublin in the years 1993-2003). Psychiatria Polska 41, 350-364.

Pine D.S., Goldstein R.B., Wolk S. \& Weissman M.M. (2001). The association between childhood depression and adulthood body mass index. Pediatrics 107, 1049-1056.

Pinhas-Hamiel O., Modan-Moses D., Herman-Raz M. \& Reichman B. (2009). Obesity in girls and penetrative sexual abuse in childhood. Acta Paediatrica 98, 144-147.

Power C., Manor O. \& Matthews S. (2003). Child to adult socioeconomic conditions and obesity in a national cohort. International Journal of Obesity and Related Metabolic Disorders 27, 1081-1086.

Preti A., Incani E., Camboni M.V., Petretto D.R. \& Masala C. (2006). Sexual abuse and eating disorder symptoms: the mediator role of bodily dissatisfaction. Comprehensive Psychiatry 47, 475-481.

Ribasés M., Gratacòs M., Fernández-Aranda F., Bellodi L., Boni C., Anderluh M., Cavallini M.C., Cellini E., Di Bella D., Erzegovesi S., Foulon C., Gabrovsek M., Gorwood P., Hebebrand J., Hinney A., Holliday J., Hu X., Karwautz A., Kipman A., Komel R., Nacmias B., Remschmidt H., Ricca V., Sorbi S., Wagner G., Treasure J., Collier D.A. \& Estivill X. (2004). Association of BDNF with anorexia, bulimia and age of onset of weight loss in six European populations. Human Molecular Genetics 13, 1205-1212.

Roehrig M., Masheb R.M., White M.A. \& Grilo C.M. (2009). Dieting frequency in obese patients with binge eating disorder: Behavioral and metabolic correlates. Obesity 17, 481-486.

Rohde P., Ichikawa L., Simon G.E., Ludman E.J., Linde J.A., Jeffery R.W. \& Operskalski B.H. (2008). Associations of child sexual and physical abuse with obesity and depression in middle-aged women. Child Abuse and Neglect 32, 878-887.

Sanci L., Coffey C., Epi G.D., Olsson C., Reid S., Carlin J.B. \& Patton G. (2008). Childhood sexual abuse and eating disorders in females. Archives of Pediatrics \& Adolescent Medicine 162, 261-267.

Shin N.Y. \& Shin M.S. (2008). Body dissatisfaction, self-esteem, and depression in obese Korean children. Journal of Pediatrics 152, 502-506.

Shisslak C.M., Pazda S.L. \& Crago M. (1990). Body weight and bulimia as discriminators of psychological characteristics among anorexic, bulimic, and obese women. Journal of Abnormal Psychology 99, 380-384.

St Clair D. (2009). Copy number variation and schizophrenia. Schizophrenia Bulletin 35, 9-12.

Stunkard A.J., Foch T.T. \& Hrubec Z. (1986). A twin study of human obesity. Journal of American Medical Association 256(1), 51-54.

Taylor S.J., Viner R., Booy R., Head J., Tate H., Brentnall S.L., Haines M., Bhui K., Hillier S. \& Stansfeld S. (2005). Ethnicity, socioeconomic status, overweight and underweight in East London adolescents. Ethnicity and Health 10, 113-128.

Terres N.G., Pinheiro R.T., Horta B.L., Pinheiro K.A.T. \& Horta L.L. (2006). Prevalence and factors associated to overweight and obesity in adolescents. Revista de Saude Publica 40, 627-633.

Thorleifsson G., Walters G.B., Gudbjartsson D.F., Steinthorsdottir V., Sulem P., Helgadottir A., Styrkarsdottir U., Gretarsdottir S., Thorlacius S., Jonsdottir I., Jonsdottir T., Olafsdottir E.J., Olafsdottir G.H., Jonsson T., Jonsson F., Borch-Johnsen K., Hansen T., Andersen G., Jorgensen T., Lauritzen T., Aben K.K., Verbeek A.L., Roeleveld N., 
Kampman E., Yanek L.R., Becker L.C., Tryggvadottir L., Rafnar T., Becker D.M., Gulcher J., Kiemeney L.A., Pedersen O., Kong A., Thorsteinsdottir U. \& Stefansson K. (2009). Genome-wide association yields new sequence variants at seven loci that associate with measures of obesity. Nature Genetics 41, 18-24.

Troisi A., Di Lorenzo G., Alcini S., Nanni R.C., Di Pasquale C. \& Siracusano A. (2006). Body dissatisfaction in women with eating disorders: Relationship to early separation anxiety and insecure attachment. Psychosomatic Medicine 68, 449-453.

Willer C.J., Speliotes E.K., Loos R.J., Li S., Lindgren C.M., Heid I.M., Berndt S.I., Elliott A.L., Jackson A.U., Lamina C., Lettre G., Lim N., Lyon H.N., McCarroll S.A., Papadakis K., Qi L., Randall J.C., Roccasecca R.M., Sanna S., Scheet P., Weedon M.N., Wheeler E., Zhao J.H., Jacobs L.C., Prokopenko I., Soranzo N., Tanaka T., Timpson N.J., Almgren P., Bennett A., Bergman R.N., Bingham S.A., Bonnycastle L.L., Brown M., Burtt N.P., Chines P., Coin L., Collins F.S., Connell J.M., Cooper C., Smith G.D., Dennison E.M., Deodhar P., Elliott P., Erdos M.R., Estrada K., Evans D.M., Gianniny L., Gieger C., Gillson C.J., Guiducci C., Hackett R., Hadley D., Hall A.S., Havulinna A.S., Hebebrand J., Hofman A., Isomaa B., Jacobs K.B., Johnson T., Jousilahti P., Jovanovic Z., Khaw K.T., Kraft P., Kuokkanen M., Kuusisto J., Laitinen J., Lakatta E.G., Luan J., Luben R.N., Mangino M., McArdle W.L., Meitinger T., Mulas A., Munroe P.B., Narisu N., Ness A.R., Northstone K., O'Rahilly S., Purmann C., Rees M.G., Ridderstråle M., Ring S.M., Rivadeneira F., Ruokonen A., Sandhu
M.S., Saramies J., Scott L.J., Scuteri A., Silander K., Sims M.A., Song K., Stephens J., Stevens S., Stringham H.M., Tung Y.C., Valle T.T., Van Duijn C.M., Vimaleswaran K.S., Vollenweider P., Waeber G., Wallace C., Watanabe R.M., Waterworth D.M., Watkins N., Wellcome Trust Case Control Consortium, Witteman J.C., Zeggini E., Zhai G., Zillikens M.C., Altshuler D., Caulfield M.J., Chanock S.J., Farooqi I.S., Ferrucci L., Guralnik J.M., Hattersley A.T., Hu F.B., Jarvelin M.R., Laakso M., Mooser V., Ong K.K., Ouwehand W.H., Salomaa V., Samani N.J., Spector T.D., Tuomi T., Tuomilehto J., Uda M., Uitterlinden A.G., Wareham N.J., Deloukas P., Frayling T.M., Groop L.C., Hayes R.B., Hunter D.J., Mohlke K.L., Peltonen L., Schlessinger D., Strachan D.P., Wichmann H.E., McCarthy M.I., Boehnke M., Barroso I., Abecasis G.R., Hirschhorn J.N. \& Genetic Investigation of Anthropometric Traits Consortium (2009). Six new loci associated with body mass index highlight a neuronal influence on body weight regulation. Nature Genetics 41, 25-34.

World Health Organization (2000). Obesity: Preventing and Managing the Global Epidemic. WHO Technical Report Series 894. WHO: Geneva.

Wonderlich S.A., Connolly K.M. \& Stice E. (2004). Impulsivity as a risk factor for eating disorder behavior: Assessment implications with adolescents. International Journal of Eating Disorders 36, 172-182.

Yeomans M.R., Leitch M. \& Mobini S. (2008). Impulsivity is associated with the disinhibition but not restraint factor from the Three Factor Eating Questionnaire. Appetite 50, 469-476. 